\author{
Giovanni Bosio* - Crystal CooKe-McEwen**
}

\title{
Insects collected from wood infested with Pityophthorus juglandis Blackman (Coleoptera Curculionidae Scolytinae) in the Piemonte region, Northwestern Italy
}

\begin{abstract}
Riassunto: Insetti raccolti da rami infestati da Pityophthorus juglandis Blackman (Coleoptera Curculionidae Scolytinae) in Piemonte.
Viene segnalata la presenza in Piemonte della malattia dei "mille cancri" del noce nero e del suo vettore, lo scolitide Pityophthorus juglandis Blackman. Sulla base dello studio degli aplotipi dello scolitide l'areale di provenienza degli esemplari raccolti è probabilmente la California settentrionale. Da legno infestato da $P$. juglandis sono stati ottenuti diversi parassitoidi. Tra questi viene segnalato per la prima volta in Europa il genere Neocalosoter Girault \& Dodd (Hymenoptera Pteromalidae Cerocephalinae), verosimilmente introdotto insieme al suo ospite. Due esemplari di Theocolax spp. sono descritti come anomalie morfologiche e con origini geografiche sconosciute.
\end{abstract}

\begin{abstract}
The walnut twig beetle, Pityophthorus juglandis Blackman (Coleoptera Curculionidae Scolytinae), and thousand cankers disease are documented in the Piemonte region of Northern Italy for the first time. Northern California is found to be the likely origin of the Piemonte walnut twig beetles based on the comparison of $\mathrm{CO} 1$ haplotypes. Multiple species of parasitoids have been reared from black walnut wood infested with the invasive walnut twig beetle. These rearings constitute the first record of the genus Neocalosoter Girault \& Dodd (Hymenoptera Pteromalidae Cerocephalinae) in Europe and are likely due to accidental introduction along with the host beetle. Two specimens of Theocolax spp. are described as morphological anomalies with unknown geographical origins.
\end{abstract}

Key words: Pityophthorus juglandis, Neocalosoter, Theocolax, black walnut, walnut twig beetle, thousand cankers disease, parasitoids, Piemonte.

\section{INTRODUCTION}

The walnut twig beetle (WTB), Pityophthorus juglandis Blackman (Coleoptera Curculionidae Scolytinae), is native to New Mexico, Arizona, Texas, California (USA) and Chihuahua (Mexico), where it lives on Arizona walnut, Juglans major (Torr.) A. Heller, and possibly two other endemic species $J$. californica S. Watson and J. hindsii (Jeps.) Jeps. ex R.E. $\mathrm{Sm}$. In the last two decades, this beetle has spread to central and eastern United States becoming a major pest in black walnut Juglans nigra L. The beetle vectors thousand cankers disease (TCD) by spreading the pathogenic fungus Geosmithia morbida Kolařík et al. (Kolařík et al., 2011, Seybold et al., 2010). Symptoms of this disease were also found in September 2013 in Veneto region (Northeastern Italy) on black walnut trees, revealing the presence of both $P$. juglandis and $G$. morbida for the first time in Europe (Montecchio \& Faccoli, 2014), later discovered also on the European walnut J. regia L. (Montecchio et al., 2014). In July
2014 the pest alone was also reported in the municipality of Marmirolo (province of Mantova), in Lombardia region. The presence of both TCD and its vector have also been recently reported on J. nigra trees in the municipality of Robecco sul Naviglio (Milano province) (Regione Lombardia, 2016). The scolytid alone was also detected in Friuli Venzia Giulia region (Pordenone province) in 2015 (Montecchio et al., 2016). After the first reports in Italy and the drawing up of a Pest Risk Analysis for Thousand cankers disease, P. juglandis has been included in the Alert List Annex 2 of the European Plant Protection Organization (EPPO, 2015).

Juglans nigra has been planted in the past in Italy for high quality timber production, but its value has decreased over the last twenty years. Nevertheless this species is still quite common in city parks and also in the fields as isolated trees or specific plantations. In spring 2015, two phytosanitary inspectors visited a black walnut plantation near the municipality of

\footnotetext{
*Giovanni Bosio, Settore Fitosanitario e Servizi Tecnico-scientifici, Regione Piemonte, Via Livorno 60, 10144 Torino (TO), Italy. E-mail: giovanni.bosio@regione.piemonte.it

${ }^{* *}$ Crystal Cooke-McEwen, University of Maryland, Department of Entomology, 4291 Fieldhouse Dr., College Park, MD 20742, USA. E-mail: mcewenidae@gmail.com
} 
Rondissone, 20 kilometers north of Torino city. Approximately two hundred 30 year old trees were just cut down and stacked on the ground making it possible to observe beetle entry holes on the stems and branch die-back. Presence of both P. juglandis and G. morbida was confirmed for the first time in Piemonte.

Consequently, in summer 2015, the Phytosanitary Service of Piemonte region started a survey of some black walnut growing sites to detect other possible TCD outbreaks. During summer inspections a second black walnut plantation near the city of Novara (locality: Olengo) was found to be infected with TCD but, in this site, P. juglandis was attacked by two hymenopteran ectoparasitoids: a Theocolax Westwood species and a Neocalosoter Girault \& Dodd species (Hymenoptera Pteromalidae Cerocephalinae). While Theocolax has species found around the world, Neocalosoter has not been documented in Europe. This may suggest an accidental introduction of at least one North American parasitoid in addition to the black walnut timber products infested by $P$. juglandis. Later samplings, carried out in different black walnut growing sites of Torino and Cuneo counties in October, 2016, revealed more associated insects and potential parasitoids.

\section{MATERIALS AND METHODS}

Collection and rearing of specimens. Logs from downed black walnut trees in Rondissone were examined in lab to collect beetles and to identify the pathogenetic fungus causing cankers on the stems. A few specimens were sent to Dr. Faccoli at the Department of Agronomy, Food, Natural Resources, Animals and the Environment, University of Padova to confirm the identification of the pest. In summer 2015 four sites (Novara locality Olengo, Bassignana, Verolengo, Garzaia di Valenza) containing black walnut trees were monitored monthly through visual inspections and the use of a 4-multifunnel trap (Econex, Murcia, Spain) for each locality, each baited with the specific WTB pheromone (Contech Enterprise, Victoria B.C., Canada).

In the Olengo site, where a few trees showed TCD symptoms, parts of infested stems were cut and transported inside plastic bags to the Phytosanitary laboratory in Torino. Twenty-eight logs with WTB boring holes, each about fifteen $\mathrm{cm}$ long by two to three $\mathrm{cm}$ in diameter, were stored in emergence traps. Each emergence trap consisted of a paperboard box with two holes closed by transparent plastic vials to catch specimens emerging from the logs and attracted by the daylight. Temperatures in the laboratory were held constant at around $20^{\circ} \mathrm{C}$. Observations ran from September 4 to October 31, about twenty days after the last emergence of beetles or parasitoids.

Logs were dissected under a Leica M205C stereomicroscope and using Leica application Suite (LaS) V 4.2 module to take pictures of WTB and parasitoids instars. On September 15 two logs from Olengo, each $9 \mathrm{~cm}$ long and with a diameters of 1.5 and $1.8 \mathrm{~cm}$, were dissected to count the different instars of $P$. juglandis and its parasitoids. Specimens collected during these dissections were kept in absolute alcohol.

During 2016 summer and fall, other logs (about 5 twigs, $20 \mathrm{~cm}$ long by $1.5-3 \mathrm{~cm}$ in diameter) from nine black walnut growing sites of different Piemonte counties, were stored in emergence traps at the Phytosanitary laboratory in Turin. Also 43 logs from the Olengo site were kept in paperboard boxes in the same period, followed by other 10 logs collected at the end of February, 2017.

Adults and young instars of the WTB and of various species of parasitoids were sent to the Department of Entomology - University of Maryland for identification and molecular investigations. Other specimens, putative predator species, were sent to Italian or USDA experts.

Specimen preparation and identification. Dehydrated wasp specimens were shipped to the United States of America for identification. Fresh and post-extraction specimens were point mounted for examination. The female Theocolax sp.1 specimen had the remaining fore and hind wing slide mounted in Canada balsam because it was folded in a way that obstructed viewing of characters. Color photos were taken using the EntoVision micro-imaging system with a Leica M16 zoom lens and JVC KY-75U 3-CCD digital video camera attached to a M16 column on a Wild M-5 stereo microscope following Buffington \& van Noort (2007). Complete point mounted, uncoated specimens were used in a Hitachi TM3000 desktop scanning electron microscope (SEM) set to charge up reduction and used in Analy mode. Parasitoids and thrips were deposited at the Smithsonian National Museum of Natural History (NMNH), Washington DC, USA, while other specimens are still in the laboratory of the Phytosanitary Service in Torino. 
Sequencing. Total DNA was extracted from whole adults that were soaked a minimum of 4 hours in extraction buffer and proteinase $\mathrm{K}$. The standard DNeasy ${ }^{\circledR}$ tissue kit spin column protocol was used with the exception of the last step not being repeated to maintain higher DNA concentration in the extract. Cytochrome oxidase subunit 1 (CO1) was amplified in two $P$. juglandis specimens using the primers LepCo1490Fand LepCo2198R primers, all other primers in Tab. 1 were used for the Neocalosoter, Theocolax and braconid wasps. Polymerase chain reaction (PCR) amplifications for P. juglandis, Neocalosoter and two Theocolax specimens used a PCR master mix from Syd labs. The remaining Theocolax specimens were sequenced at a different lab and used the Taq DNA Polymerase kit from Qiagen. The PCR thermal cycling programs and primers are in Tab. 1. The thermal cycle program used with the LepCo primers was a touchdown cycle that decreased the annealing temperature $0.4^{\circ} \mathrm{C}$ with each cycle between $55^{\circ} \mathrm{C}$ and $45^{\circ} \mathrm{C}$. Unpurified P. juglandis PCR samples were sent to GeneWiz, Inc. for sequencing. The PCR products for the wasps were processed at the Smithsonian NMNH Laboratories of Analytical Biology.

Basecalling was checked and sequences trimmed using Geneious ${ }^{\circledR}$ v. 7.1.5. Pityophthorus juglandis sequences were compared to haplotype sequences using BLAST (Altschul et al., 1990) and aligned using MAFFT v.7 (Katoh \& Standley, 2013). All sequences were deposited in GenBank with the following accession numbers: KX809920- KX809922, KX809924-KX809928， KX809930-KX809937, KX781251-KX781252, KX781254-KX781258, KX774310, and MG182640-MG182642.

\section{Results AND Discussion}

Examination of "Rondissone" logs in 2014 revealed a low number of beetles in the galleries under the bark. This was consistent with the origin of those logs from trees already cut one month before. It was confirmed that the specimens belonged to the North American species Pityophthorus juglandis (Faccoli, pers. comm.). Also the molecular analysis identified the fungus as G. morbida (Gullino and Mason, pers. comm.) confirming the presence of TCD. No parasitoids were detected.

During the 2015 TCD survey in Piemonte the 4multifunnel traps caught WTB adults only in one site of the four checked. It was a mixed plantation $\sim 20$ years old and 13 hectares in size, near Olengo (Novara municipality). Black walnut trees were mixed with other hardwood plants such as Juglans regia L., Fraxinus excelsior L., Quercus rubra L. and Tilia spp.

Tab. 1. Primers used for PCR amplification of CO1 and parts of 28s in P. juglandis, Theocolax wasps and Neocalosoter wasps.

\begin{tabular}{|c|c|c|c|c|}
\hline \multirow[t]{2}{*}{ Primer } & \multirow[t]{2}{*}{ Source, Sequence } & \multicolumn{2}{|c|}{ Cycling Conditions } & \multirow[t]{2}{*}{ Extension } \\
\hline & & Denaturation & Annealing & \\
\hline $\mathrm{CO} 1$ & Hebert et al., 2004 & & & \\
\hline LepCo1490F & 5' ATTCAACCAATCATAAAGATATTGG 3' & $94^{\circ} \mathrm{C}(30 \mathrm{sec})$ & $55-0.4^{\circ} \mathrm{C}(30 \mathrm{sec})$ & $72^{\circ} \mathrm{C}(1 \mathrm{~min})$ \\
\hline LepCo2198R & 5' TAAACTTCTGGATGTCCAAAAAATCA 3' & $94^{\circ} \mathrm{C}(30 \mathrm{sec})$ & $45^{\circ} \mathrm{C}(30 \mathrm{sec})$ & $72^{\circ} \mathrm{C}(2 \mathrm{~min})$ \\
\hline \multirow{3}{*}{$\begin{array}{l}\text { CO1 } \\
\text { LCO-1490F } \\
\text { HCO_2198 }\end{array}$} & Folmer et al., 1994 & $93^{\circ} \mathrm{C}(15 \mathrm{sec})$ & $46^{\circ} \mathrm{C}(45 \mathrm{sec})$ & $68^{\circ} \mathrm{C}(45 \mathrm{sec})$ \\
\hline & 5' GGTCAACAAATCATAAAGATATTGG 3' & & & \\
\hline & 5' TAAACTTCAGGGTGACCAAAAAATCA 3' & & & \\
\hline \multirow{3}{*}{$\begin{array}{l}28 \mathrm{~S} \\
\text { D2F } \\
\text { D2Ra }\end{array}$} & Schmidt et al., 2011 & $94^{\circ} \mathrm{C}(1 \mathrm{~min})$ & $55^{\circ} \mathrm{C}(1 \mathrm{~min})$ & $72^{\circ} \mathrm{C}(1 \mathrm{~min})$ \\
\hline & 5' CGGGTTGCTTGAGAGTGCAGC 3' & & & \\
\hline & 5' CTCCTTGGTCCGTGTTTC 3' & & & \\
\hline \multirow{3}{*}{$\begin{array}{l}28 \mathrm{~S} \\
\mathrm{D} 3 \mathrm{Fa}\end{array}$} & Modified from Nunn et al., 1996 & $94^{\circ} \mathrm{C}(1 \mathrm{~min})$ & $55^{\circ} \mathrm{C}(1 \mathrm{~min})$ & $72^{\circ} \mathrm{C}(1 \mathrm{~min})$ \\
\hline & 5' TTGAAACACGGACCAAGGAG 3' & & & \\
\hline & Jason Mottern, USDA/Heraty Lab, UCR & & & \\
\hline D3Ra & 5' CGCCCCTATACCCAGTTC 3' & & & \\
\hline
\end{tabular}


Thousand cankers disease symptoms were not so evident: only few trees showed stems withering and dieback and presence of WTB holes was noticeable only on a few twigs. Under the bark of 2-3 cm diameter stems the typical cankers were easily detected and the presence of G. morbida was confirmed by molecular analysis in the laboratory. No symptoms were observed on the European walnut J. regia. This was the second discovery of the exotic beetle and the pathogenic fungus causing TCD in Piemonte. Presence of all WTB instars (eggs enclosed) were high in logs from Olengo black walnut trees. Cutting away the log bark also showed a relevant presence of larvae and pupae of hymenopteran parasitoids, which adults were sometimes seen walking inside the beetle galleries. Unfortunately only for two logs there was a count of the specimens detected at the stereomicroscope (Tab. 2). Paperboard boxes with Olengo site logs produced $1131 \mathrm{WBC}$ adults, 82 females of Neocalosoter sp. and 10 Theocolax sp. in the period September-October, 2015, despite being collected in late summer and the logs not being protected against desiccation in the boxes.

Data from paperboard boxes containing logs collected in 2016 (and some on February, 2017) in the site of Olengo and in other nine black walnut growing sites in different counties, together with visual inspections in other areas of Piemonte, revealed a large spread of the TCD vector in this region, accompanied by the presence of different species of putative parasitoids or predators or simply coinquilines of the WTB (Tab. 3).

DNA sequencing. The first sequences of $\mathrm{CO} 1$ from $P$. juglandis in Italy (Montecchio et al., 2014) produced a sequence (KF725084) that matched the haplotype $\mathrm{H} 2$ that is geographically widespread across the USA populations (Rugman-Jones et al., 2015). This study also found that same haplotype in one specimen (KX809937), however, another specimen
(KX809936) found in this study matched haplotype $\mathrm{H} 21$ which was only found in two localities in the USA (Rugman-Jones et al., 2015, pers. comm.). Both localities, Benton County, Oregon and Solano County, California, are in the Cascade Range region. This result suggests that the Cascade Range region may be the origin of at least some of the WTB spread in Piemonte.

Sequencing of wasp larvae was unsuccessful since no DNA was detectable on an agarose gel. Sequencing of 28S (D2 and D3) was successful for all of the parasitoid species. Sequencing of CO1 was successful for the Theocolax specimens except Theocolax sp.2. In all cases, differentiation was not possible among the sequenced regions suggesting that these specimens are closely related. More samples are required to confirm the taxonomic status of these specimens.

Parasitoids. At least three species of Cerocephalinae were collected from TCD infested wood in Piemonte. The genus Neocalosoter has not been previously documented in Europe so this finding constitutes a new record (Fig. 1). The presence of this genus in Italy is likely due to its introduction with the host beetle from North America. The collected specimens are morphologically similar to $N$. pityophthori (Ashmead) and $N$. scolytivora (Ashmead) since the diagnosis between these two species can be difficult. The Italian specimens of Neocalosoter remain unidentified for now. The authors also note that all collected specimens from this species were female. Previously, Neocalosoter species have been collected from $P$. juglandis infested wood in California (Graves et al., 2009) and Tennessee (Lambdin et al., 2015), USA. The second collected cerocephaline species could be a new species of Cerocephala Westwood (Fig. 2) and is under current review by the second author.

The third group of collected Cerocephalinae

Tab. 2. Specimens collected by stereomicroscope examination of two TCD infested logs from Novara, locality Olengo, Piemonte, Italy.

Log length (cm) Log diameter (cm) WTB adults WTB pupae Neocalosoter sp. Theocolax sp. adults Parasitoids larvae

\begin{tabular}{lllllll}
\hline 9 & 1.5 & 45 & 2 & 5 & 0 & 2 \\
\hline 9 & 1.8 & 37 & 1 & 1 & 1 & 7 \\
\hline
\end{tabular}




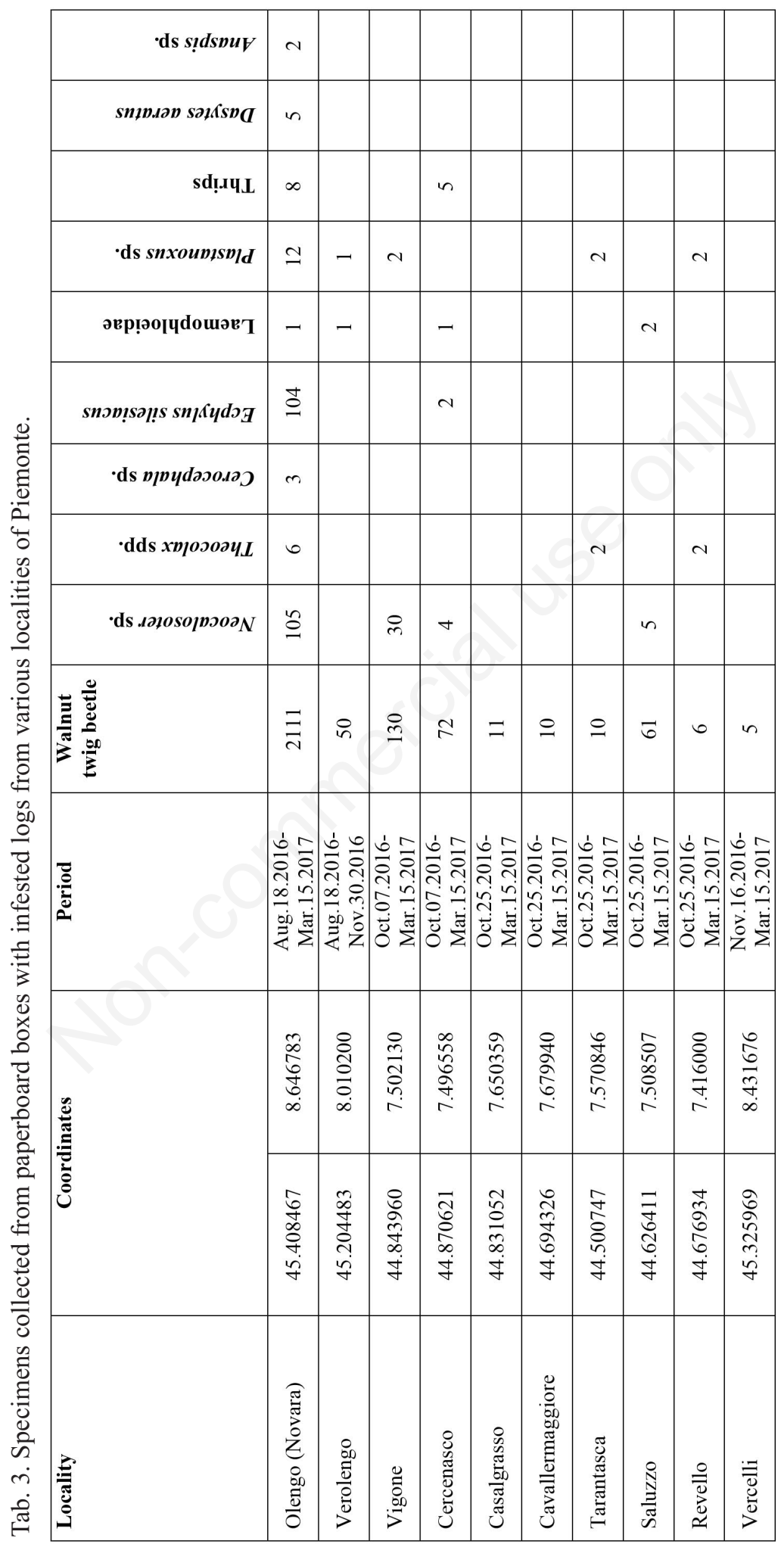


belongs to the genus Theocolax and to the T. ingens group, sharing the interantennal lamella extending more than half way to the ocelli, the presence of a patch of striations on the side of the pronotum, spines of the calcar being parallel-sided and the postmarginal vein equal in length to the stigmal vein. Most specimens morphologically fit $T$. americanus McEwen and were identified as such (Fig. 3). However, other specimens with morphological anomalies were also collected.

Theocolax sp. 1 is a female specimen similar to T. americanus but differs in that it has a reduced number of antennal segments (four flagellar segments instead of five; Fig. 4), though there is a partial suture medially on the right clava. This trait differentiates it from all other species of the genus. A male specimen with reduced number of antennal segments (five flagellomeres instead of six) was also collected. Their CO1 sequences (KX809934 ㅇ, KX809933 ðै) were identical to $T$. americanus. These specimens were left unidentified until more specimens can be obtained to clarify whether this is variation within T. americanus or diagnostic to separate a new species.

Two other female specimens of Theocolax collected in Italy appear close to T. americanus, though there was some variation in the presence of placoid sensilla on F1-F2. The presence of sensilla on particular flagellomeres has not been examined for trait consistency in Theocolax. General collection specimens (National Museum of Natural History; Smithsonian Institution; Washington, DC) were examined in T. americanus and T. elegans (Westwood) for comparison. All twenty-five T. elegans females examined also had at least one placoid sensillum on each flagellomere. Fifteen female T. americanus specimens were examined and while most had at least one placoid sensillum present on all flagellomeres a few lacked sensilla on F1. Type specimens of $T$. oblonga had placoid sensilla on F2-clava, $T$. phloeosini on F1-clava, general collection specimens of $T$. frater had placoid sensilla on F1-clava, T. bakeri on F3-clava and T. formiciformis on F2 or F3-clava. One of the specimens from Italy lacked sensilla only on F1 and therefore matched the state seen in some $T$. americanus. One more specimen lacked sensilla on F1-F2. Due to the variation in presence of placoid sensilla on flagellomeres seen in the T. americanus specimens and the lack of molecular differentiation, these specimens are tentatively identified as $T$. americanus since they match that species in other morphological characters.

Another specimen, called Theocolax sp.2, differed from T. americanus lacking placoid sensilla on F1-F3 (Fig. 5). Moreover there were only 3 striations on the side of the pronotum (Fig. 6), and it lacked the large macula along the posterior edge of the marginal-stigmal vein junction (Fig. 7). The first two traits are somewhat variable but all known $T$. americanus specimens have a macula at the marginalstigmal vein junction. The only species known to lack this macula is $T$. ingens but this specimen had propodeal sculpturing more similar to T. americanus. Also, $T$. ingens has a more complex patch of striations on the pronotal side with around 16 striations. Unfortunately CO1 could not be amplified so this specimen is left unidentified until more specimens are obtained.

The origin of the collected Theocolax wasps is uncertain. While morphological anomalies exist there was no molecular differentiation compared to $T$. americanus. This suggests that these Italian specimens are closely related to this species if not conspecific. $T$. americanus has only been collected in Colorado, USA (McEwen, 2015), suggesting that this wasp was introduced. Confirmation would require additional sampling of the species in Italy and the USA.

Other insects. Two species of thrips (Thysanoptera) were found in large numbers on trees infested with TCD. They were identified as the fungivorous thrips Hoplandrothrips ellisi Bagnall (Fig. 8) and Hoplandothrips sp. (Fig. 9). These thrips may be attracted to G. morbida or other fungi involved in decaying wood. There were also Bethylidae wasps in the genus Plastanoxus Kieffer (Fig. 10) which are known to attack wood boring beetles (Evans, 1978), though their hosts have yet to be determined in this system. A Plastanoxus sp. was reported as a parasitoid of WTB in California by Graves et al. (2009) but this was never formally published. Laemophloeidae adults (Fig. 11) of genus Cryptolestes Ganglbauer were caught in paperboard boxes from different sites and also larval stages were found in WTB galleries. Lambdin et al. (2015) reported, among natural enemies of $P$. juglandis in Eastern Tennessee, three Laemophloeidae species, usually reputed predators of Scolytinae. It's noteworthy that Plastanoxus sp. is also reported as parasitoid of Laemophloeidae. Braconidae 
wasps (Fig. 12) were also collected from TCD infested wood though it is unclear from which host. The relatively high number of the braconids from the
Olengo site paperboard boxes (Tab. 3) suggests a potential role as $P$. juglandis parasitoid. These braconids were determined as Ecphylus silesiacus

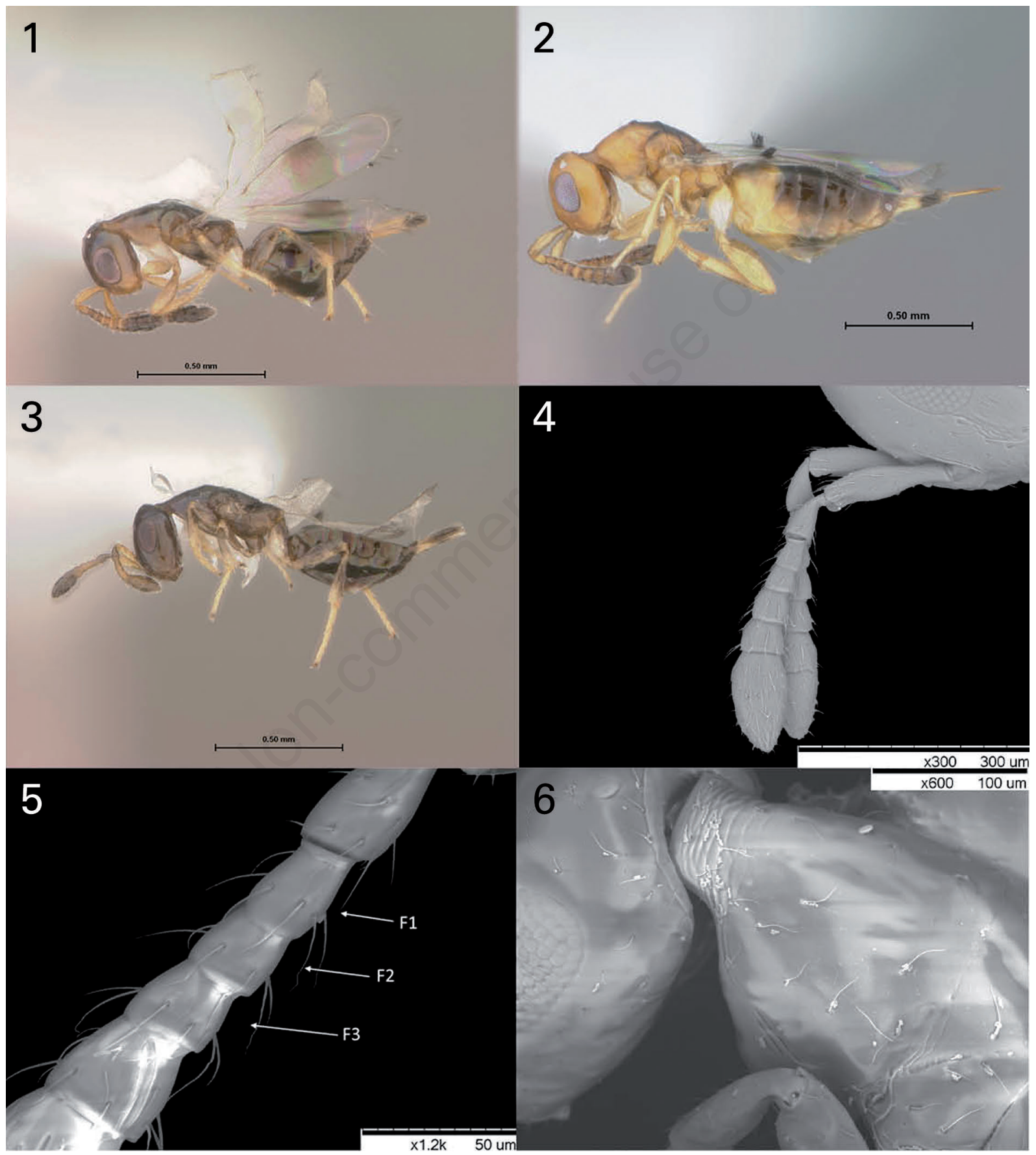

Figs. 1-6. 1 - Neocalosoter sp. $9 ; 2-$ Cerocephala sp. $9 ; 3-$ Theocolax americanus + ; 4 - Theocolax sp. + , lateral antenna; 5 - Theocolax sp. 2 +, flagellum base; 6 - Theocolax sp. 2 , side of pronotum. 
(Ratzeburg) by using BLAST (Altschul et al., 1990) to compare sequences for $\mathrm{CO} 1$ (100\% identity match to KP268034.1).
There were other insects collected during this study that are associated with the host trees but not necessarily associated with the vector of thousand

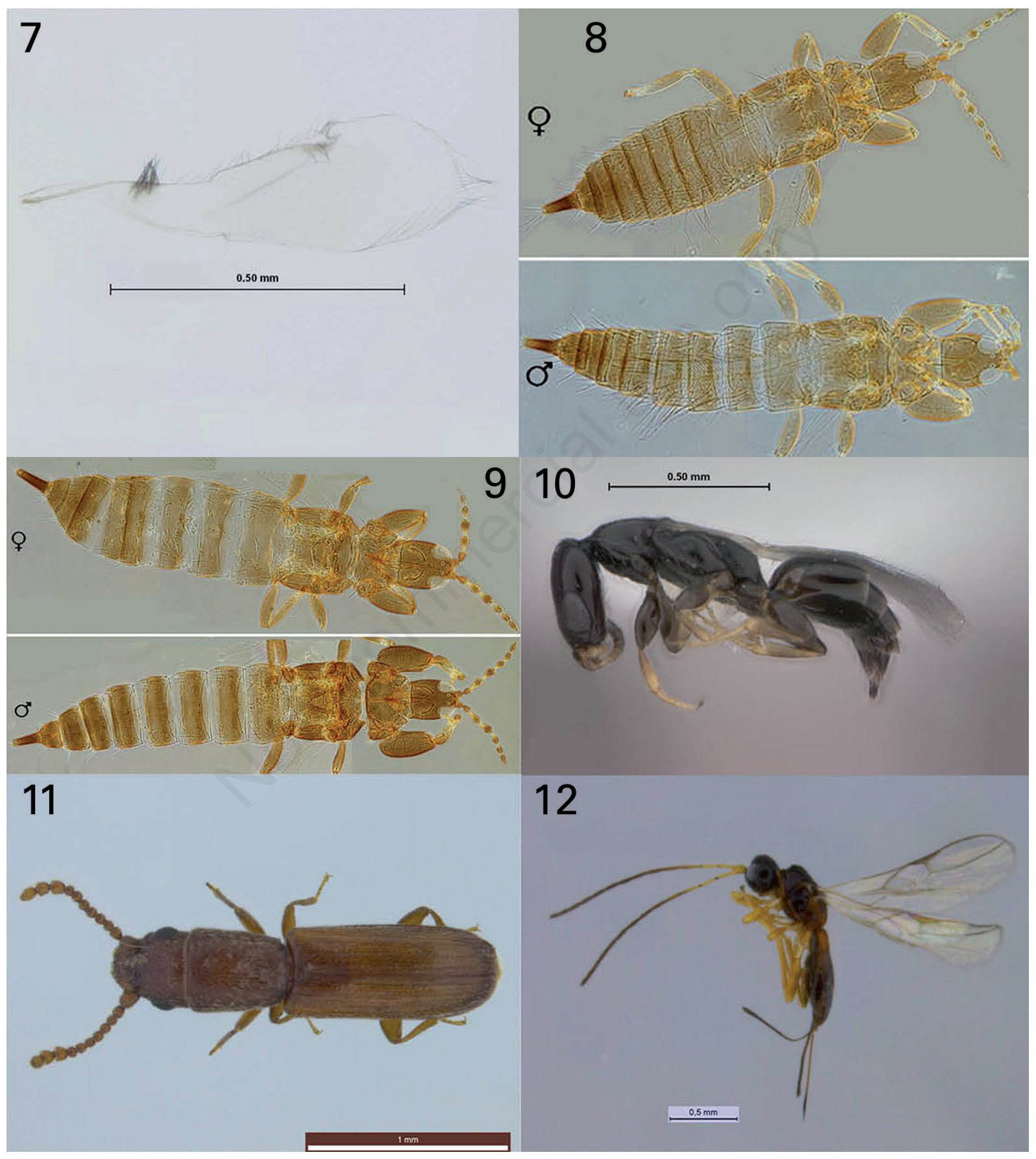

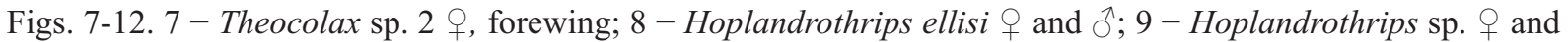
ô; 10 - Plastanoxus sp.; 11 - Laemophloeidae; 12 - Ecphylus silesiacus + . 
cankers disease. Some coleopteran belonging to Melyridae and Scraptiidae were obtained during February, 2017, from the paperboard box containing Olengo site's twigs. Specimens of the first family belong to the species Dasytes aeratus Stephens (Fig.13). These soft-wing flower beetles usually feed on pollen and small insects visiting flowers, while their larval stages live in the bark, hunting xylophagous larvae. Scraptiidae adults (false flower beetles) belong to genus Anaspis Geoffroy (Fig. 14). They live on flowers or decaying wood and their larvae develop in leaf litter or deteriorated wood.

\section{Conclusions}

Sequencing of CO1 in P. juglandis showed that the Piemonte beetles were likely introduced from the Cascade region of Northern California/Southern Oregon. However, the presence of Theocolax americanus suggests that there may have been another introduction from Colorado where this parasitoid has been collected. It should be noted that an unidentified species of Theocolax closely related to T. americanus was reared in Tennessee (Lambdin et al., 2015). Neocalosoter pityophthori had previously only been documented from WTB in Tennessee but an unidentified species of the genus was collected in California from WTB. The presence of Neocalosoter sp. in Italy does not help narrow down the possible origins of the beetle.

After the first report of TCD and WTB in North Italy in 2013, now the disease and its vector are reported from many localities of Veneto, Lombardia and Piemonte regions, attacking primarily black walnut trees but also raising questions about the risk for the more common $J$. regia. In the Piemonte region the accidental introduction of the pest has been accompanied by transport of some parasitoid species: Neocalosoter sp., possibly Theocolax americanus and possibly Plastanoxus sp. Of these, Neocalosoter sp. has the largest and more widespread population in Piemonte, but it does not seem to be able to control the exotic pest. Furthermore the galleries of $P$. juglandis in twigs and branches are already exploited by many other insects, such as species living in decaying wood. These insects are not always involved in trophic relations with the exotic scolytid but have taken advantage of the changes brought on by the beetle infestation.

\section{ACKNOWLEDGEMENTS}

The authors thank Massimo Faccoli (University of Padova) for the confirmation of $P$. juglandis identification. We are also grateful to Clotilde Gullino, Sergio Cravero and Giovanna Mason (Sett. Fitosanitario - Regione Piemonte) for the work in field and in laboratory to detect TCD symptoms and to identify G. morbida. Michael Gates (USDA-SEL) provided feedback on parasitoid identifications and comments on the paper. The authors thank Cheryle A. O'Donnell (USDA-APHIS), Robert Kula (USDASEL), Roberto Poggi (Museo Civico di Storia Naturale "G. Doria" of Genova) and Gianfranco Liberti for identifications of insects. Jason Mottern (USDA-ARS) performed the sequencing of the parasitoids. Special thanks to the Smithsonian NMNH Laboratories of Analytical Biology for use of their facilities. Thanks are given to Paul Rugman-Jones et al. (2015) for providing locality data for the specific haplotypes.
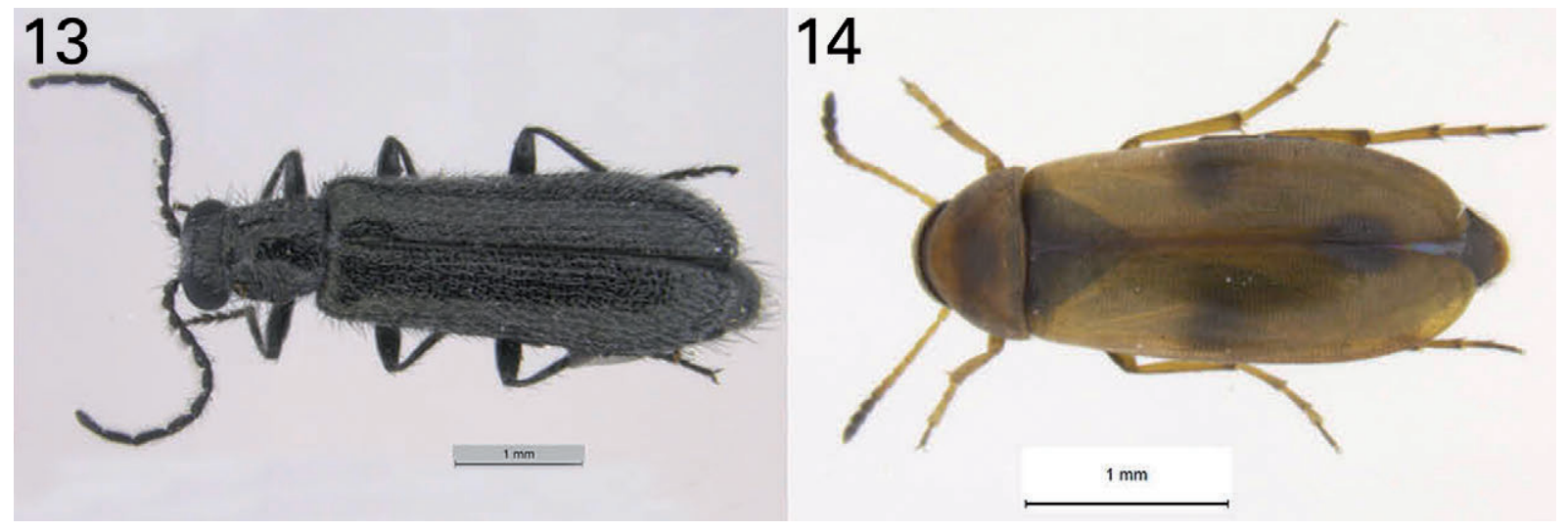

Figs. 13-14. 13 -Dasytes aeratus; 14 - Anaspis sp. 


\section{REFERENCES}

Altschul S.F., Gish W., Miller W., Myers E.W., Lipman D.J., 1990 - Basic local alignment search tool. Journal of Molecular Biology, 215: 403-410.

Buffington M.L., van NoorT S., 2007 - A world revision of the Pycnostigminae (Hymenoptera: Figitidae) with descriptions of seven new species. Zootaxa, 1392: 1-30.

EPPO, 2015 - Express PRA for Geosmithia morbida and Pityophthorus juglandis. Available from: https://gd.eppo.int/taxon/GEOHMO/documents

Evans H.E., 1978 - The Bethylidae of America north of Mexico. American Entomological Institute, Ann Arbor, Michigan.

Folmer O., Black M., Hoen W., Lutz R., VRiJenhoek R., 1994 - DNA primers for amplification of mitochondrial cytochrome c oxidase subunit I from diverse metazoan invertebrates. Molecular Marine Biology and Biotechnology, 3(5): $294-299$.

Graves A., Hishinuma S., Hamud S., SeYbold S., 2009 - Host colonization behavior of the walnut twig beetle, Pityophthorus juglandis Blackman, in California Hinds walnut. Available from: http://caforestpestcouncil.org/wpcontent/uploads/2009/05/steven-seybold-walnut.pdf. Accessed: 3 April, 2017.

Hebert P.D.N., Penton E.H., Burns J.M., Hallwachs W., 2004 - Ten species in one: DNA barcoding reveals cryptic species in the Neotropical skipper butterfly Astraptes fulgerator. Proceedings of the National Academy of Sciences of the United States of America, 101(41): 14812-14817.

KatoH K., StAndley D.M., 2013 - MAFFT multiple sequence alignment software version 7: Improvements in performance and usability. Molecular Biology and Evolution, 30(4): 772-780.

Kolařík M., FreEland E., Utley C., TisSERAT N., 2011 - Geosmithia morbida sp. nov., a new phytopathogenic species living in symbiosis with the walnut twig beetle (Pityophthorus juglandis) on Juglans in USA. Mycologia, 103(2): 325-332.

Lambdin P., Nix K., Grant J., Pausen G., Merten P., 2015 - Natural Enemies of the walnut twig beetle in Eastern Tennessee. International Journal of Research in Agriculture and Forestry, 2(9): 31-39.

McEwen C., 2015 - A new species of Theocolax Westwood (Hymenoptera: Pteromalidae: Cerocephalinae) reared from Pityophthorus juglandis Blackman (Coleoptera: Curculionidae: Scolytinae). Proceedings of the Entomological Society of Washington, 117(2): 162-178.

Montecchio L., Faccoli M., 2014 - First Record of Thousand Cankers Disease Geosmithia morbida and Walnut Twig Beetle Pityophthorus juglandis on Juglans nigra in Europe. Plant Disease, 98(5): 696.

Montecchio L., Fanchin G., Simonato M., Faccoli M., 2014 - First Record of Thousand Cankers Disease Fungal Pathogen Geosmithia morbida and Walnut Twig Beetle Pityophthorus juglandis on Juglans regia in Europe. Plant Disease, 98(10): 1445.

Montecchio L., Vettorazzo M., FACCOLi M., 2016 - Thousand cankers disease in Europe: an overview. Bulletin OEPP/EPPO Bulletin, 46(2): 335-340.

Nunn G.B., Theisen F., Christensen B., Arctander P., 1996 - Simplicity-correlated size growth of the nuclear 28S ribosomal RNA D3 expansion segment in the crustacean order Isopoda. Journal of Molecular Evolution, 42: 211-223.

REGIONE LOMBARDIA, 2016 - Geosmithia morbida o TDC (thousand canker disease) - Malattia dei mille cancri. Available from: http://www.ersaf.lombardia.it/upload/ersaf/gestionedocumentale/1_Geosmithiamonitoraggio_784_30931.pdf.

Rugman-Jones P.F., Seybold S.J., Graves A.D., Stouthamer R., 2015 - Phylogeography of the Walnut Twig Beetle, Pityophthorus juglandis, the Vector of Thousand Cankers Disease in North American Walnut Trees. PLoS One, 10(2): e0118264.

Schmidt S., De Barro P., Jamieson L., 2011 - Parasitoids of the Australian citrus whitefly, Orchamoplatus citri (Takahashi) (Hemiptera, Aleyrodidae), with description of a new Eretmocerus species (Hymenoptera, Aphelinidae). Zootaxa, 2873: 27-34.

SeYbold S.J., Graves A.D., Coleman T.W., 2010 - Walnut twig beetle: Update on the biology and chemical ecology of a vector of an invasive fatal disease of walnut in the western U.S., pp. 55-57. In: McManus KA, Gottschalk KW, editors. Proceedings, 21st U.S. Department of Agriculture Interagency Research Forum on Invasive Species 2010. USDA-FS: Northern Research Station. 